\title{
Hubungan Tingkat Risiko Obstructive Sleep Apnea dan Sindroma Metabolik dengan Fungsi Kognitif Global
}

\section{The Correlation of Obstructive Sleep Apnea Risk level and Metabolic Syndrome with Global Cognitive Functions}

\author{
Herpan Syafii $H^{1}$, Yanna Indrayana ${ }^{2}$, Rina Lestari \\ ${ }^{1}$ Laboratorium Neurologi Fakultas Kedokteran Universitas Mataram Mataram \\ ${ }^{2}$ Laboratorium IImu Penyakit Jantung dan Pembuluh Darah Fakultas Kedokteran Universitas Mataram Mataram \\ ${ }^{3}$ Laboratorium IImu Penyakit Paru Fakultas Kedokteran Universitas Mataram Mataram
}

\begin{abstract}
ABSTRAK
Obstructive sleep apnea (OSA) berhubungan dengan peningkatan risiko gangguan fungsi kognitif, dan gangguan fungsi kognitif tersebut juga terkait dengan komponen sindrom metabolik (hipertensi, diabetes melitus, obesitas sentral, dan dislipidemia). Penegakan diagnosis penyakit tersebut membutuhkan keahlian khusus, waktu pemeriksaan yang lama, dan mahal, oleh karena itu penapisan tingkat risiko OSA dengan instrumen sederhana sangat diperlukan. Penelitian ini bertujuan untuk menginvestigasi tingkat risiko OSA dan sindroma metabolik dengan fungsi kognitif global. Desain potong lintang dilakukan dengan melibatkan 89 subjek yang datang dalam acara Car Free Day dan memenuhi kriteria inklusi. Data yang dikumpulkan meliputi usia, jenis kelamin, riwayat hipertensi, dislipidemia, diabetes melitus, indeks massa tubuh (IMT), obesitas sentral, tingkat risiko OSA, dan fungsi kognitif global. Tingkat risiko OSA dinilai dengan menggunakan instrumen STOP-BANG Questionnaire dan fungsi kognitif global menggunakan instrumen Clock Drawing Test (CDT). Hasil penelitian menunjukkan terdapat perbedaan bermakna dalam hal frekuensi subjek dengan tingkat risiko tinggi OSA $(p=0,042)$ dan subjek dengan diabetes melitus $(p=0,04)$ antara kelompok subjek dengan status fungsi kognitif global normal dan menurun. Hasil penelitian juga menunjukkan bahwa hanya satu komponen sindroma metabolik, yaitu hipertensi yang berhubungan dengan tingkat risiko OSA $(p<0,001)$, sedangkan diabetes melitus, obesitas sentral dan dislipidemia tidak. Dapat disimpulkan bahwa tingkat risiko OSA berhubungan dengan status fungsi kognitif global dan komponen sindroma metabolik yang berperan adalah diabetes melitus dan hipertensi.
\end{abstract}

Kata Kunci: Fungsi kognitif global, obstructive sleep apnea, penapisan, sindrom metabolik, tingkat risiko

\begin{abstract}
Obstructive sleep apnea (OSA) is related to an increased risk of cognitive function impairment, and cognitive impairment is also associated to metabolic syndrome components (hypertension, diabetes mellitus, central obesity, and dyslipidemia). The diagnosis of the disease requires special skills, long examination time, and is expensive; therefore, OSA risk screening with simple instruments is necessary. This study aimed to investigate the OSA risk level and metabolic syndrome with global cognitive function. Cross-cut design was carried out by involving 89 subjects who came in a Car Free Day event and met the inclusion criteria. Data collected included age, gender, hypertension history, dyslipidemia, diabetes mellitus, body mass index (BMI), central obesity, OSA risk level, and global cognitive function. OSA risk level was assessed using STOPBANG Questionnaire while global cognitive function by using Clock Drawing Test (CDT) instrument. The results show a significant difference in the frequency of subjects with high risk OSA ( $p=0.042)$ and subjects with diabetes mellitus ( $p=0.04)$ between the subjects with normal and declining global cognitive function status. The results also show that only one component of metabolic syndrome, i.e. hypertension, is associated with OSA risk level $(p<0.001)$, whereas diabetes mellitus, central obesity, and dyslipidemia are not. It can be concluded that OSA risk level is related to the status of global cognitive function and the acting components of metabolic syndrome are diabetes mellitus and hypertension.
\end{abstract}

Keywords: Global cognitive function, metabolic syndrome, obstructive sleep apnea, risk level, screening

Korespondensi: Herpan Syafii H. Laboratorium Neurologi Fakultas Kedokteran Universitas Mataram, Jl. Pendidikan No. 37 Mataram Nusa Tenggara Barat 83125 Tel. 08175770062 Email: herpanharahap@yahoo.co.id 


\section{PENDAHULUAN}

Obstructive sleep apnea (OSA) merupakan salah satu bentuk gangguan tidur yang berkaitan dengan peningkatan risiko sindrom metabolik, penyakit kardiovaskuler, dan gangguan fungsi kognitif (1-3). Prevalensi OSA sangat bervariasi di berbagai negara di dunia, dengan rentang $9 \%$ sampai dengan $38 \%$, dan lebih tinggi pada populasi lakilaki (4). Data prevalensi OSA di Indonesia saat ini masih belum tersedia, namun satu penelitian pada populasi normal di Jakarta menunjukkan bahwa prevalensi OSA di wilayah tersebut sebesar $49,5 \%$ (5).

Penegakan diagnosis OSA dengan pemeriksaan polisomnografi, membutuhkan keahlian khusus, waktu pemeriksaan yang lama, serta mahal (6). Oleh karena itu meskipun penapisan awal tingkat risiko OSA pada individu sangat dibutuhkan pada tingkat populasi, konfirmasi diagnosis hanya dapat dilakukan pada individu-individu yang memiliki tingkat risiko tinggi. Untuk penapisan tingkat risiko OSA dibutuhkan instrumen yang sederhana, mudah diaplikasikan, dan tervalidasi. Instrumen STOPBANG Questionnaire merupakan instrumen yang tepat untuk tujuan tersebut. Instrumen ini sudah tervalidasi pada populasi umum maupun pasien di rumah sakit (7-9). Instrumen ini juga telah digunakan pada populasi penduduk Asia (10).

Gangguan fungsi kognitif terkait OSA, secara teori berhubungan erat dengan terjadinya hipoksia intermiten pada pasien OSA yang mencetuskan disfungsi endotel pembuluh darah otak. Hal ini mengakibatkan terbentuknya radikal bebas dan terjadinya respon inflamasi di otak yang mengarah pada proses neurodegenerasi (11). Struktur di otak yang paling rentan terhadap proses neurodegenerasi tersebut terutama adalah hipokampus dan lobus frontalis, yang merupakan struktur penting untuk terbentuknya fungsi kognitif (12). Satu studi menunjukkan bahwa proses neurodegenerasi terkait OSA semakin meningkat dengan keberadaan sindrom metabolik (13).

Sindrom metabolik merupakan salah satu faktor risiko untuk terjadinya OSA. Disamping itu, beberapa komponen sindrom metabolik yaitu hipertensi dan obesitas, merupakan komponen penyusun STOP-BANG Questionnaire $(7,14)$. Gangguan fungsi kognitif pada pasien OSA dapat merupakan akibat dari penyakit OSA itu sendiri atau berkaitan dengan faktor risiko OSA, diantaranya komponen sindrom metabolik. Studi pada sub-populasi Kota Mataram menemukan bahwa diantara komponen sindrom metabolik hipertensi memiliki prevalensi yang paling tinggi (15). Penelitian ini ditujukan untuk menginvestigasi pengaruh faktor dan tingkat risiko OSA terhadap fungsi kognitif global pada subjek yang belum pernah terdiagnosis OSA sebelumnya di Kota Mataram.

\section{METODE}

Penelitian ini merupakan penelitian potong lintang yang melibatkan subjek yang datang dalam kegiatan Car Free Day yang rutin diadakan setiap hari minggu di Kota Mataram, Nusa Tenggara Barat. Subjek dipilih menggunakan teknik non probability sampling dengan kriteria inklusi laki-laki atau perempuan berusia $\geq 40$ tahun, sadar penuh, dan bersedia untuk berpartisipasi sebagai subjek penelitian. Subjek dikeluarkan jika memiliki riwayat terdiagnosis OSA atau memutuskan untuk tidak melanjutkan partisipasinya dalam penelitian. Penelitian ini dikerjakan selama 3 bulan, Februari-April 2017, setelah mendapatkan persetujuan dari komisi etik. Pelaksanaan penelitian ini mendapatkan persetujuan dari Komisi Etik Penelitian Kesehatan Universitas Mataram dengan Surat Persetujuan Etik No. 81/UN18.8/ETIK/2017.

Data yang dikumpulkan dalam penelitian ini meliputi karakteristik demografis (usia dan jenis kelamin) dan klinis (hipertensi, diabetes melitus, indeks massa tubuh (IMT), obesitas sentral, dislipidemia, tingkat risiko OSA, dan status fungsi kognitif global) subjek penelitian. Data tersebut didapatkan melalui wawancara terstruktur, pemeriksaan fisik terhadap subjek, dan pemeriksaan laboratorium. Subjek dikategorikan mengalami obesitas sentral jika nilai lingkar pinggang $\geq 90 \mathrm{~cm}$ untuk laki-laki dan $\geq 80 \mathrm{~cm}$ untuk perempuan dan dikategorikan dislipidemia jika kadar kolesterol HDL serum $<40 \mathrm{mg} / \mathrm{dl}$ untuk laki-laki dan $<50 \mathrm{mg} /$ dl untuk perempuan (16).

Tingkat risiko OSA diukur menggunakan instrumen STOPBANG Questionnaire. Instrumen tersebut terdiri dari 8 pertanyaan yang mengkonfirmasi apakah subjek tidur ngorok waktu malam hari (snoring), memiliki perasaan mudah lelah (tiredness), episode tidak bernapas sewaktu tidur malam yang dapat dilihat oleh pasangannya (observed apnea), hipertensi (pressure), body mass index (BMI) $>35 \mathrm{~kg} / \mathrm{m}^{2}$, usia (age) $>50$ tahun, hasil pengukuran lingkar leher (neck circumference) $>40 \mathrm{~cm}$, dan jenis kelamin (gender) laki-laki. Setiap pertanyaan diberi skor 1 jika memiliki jawaban "ya" dan skor 0 jika memiliki jawaban "tidak." Tingkat risiko OSA dikategorikan menjadi 2 kelompok, yaitu tingkat risiko tinggi jika memiliki skor 4-8 dan rendah jika skor 0-3 (7).

Penilaian fungsi kognitif global dilakukan menggunakan instrumen Clok Drawing Test (CDT), suatu instrumen tervalidasi yang sederhana untuk penapisan fungsi kognitif global dan penerapannya tidak dipengaruhi oleh tingkat pendidikan $(17,18)$. Pada pemeriksaan CDT, subjek diminta untuk menggambar lingkaran jam dinding lengkap dengan angka-angkanya pada posisi yang benar dan menggambar jarum jam yang menunjukkan pukul sebelas lebih sepuluh menit. Skor diberikan pada 4 komponen penilaian, antara lain gambar berbentuk lingkaran tertutup, angka mulai dari 1 sampai 12 , posisi angka benar, dan jarum jam menunjukkan pukul 11 lebih 10 menit. Tiap komponen penilaian tersebut diberikan nilai 1 bila benar dan 0 bila salah. Subjek dikategorikan menjadi 2 kelompok, yaitu kelompok dengan status fungsi kognitif global normal jika memiliki skor total CDT 4 dan menurun jika memiliki skor total CDT 0-3 (19).

Data karakteristik klinis dan demografis subjek disajikan dalam bentuk nilai rerata dan persentase. Perbedaan rerata usia subjek pada kedua kelompok status fungsi kognitif global dianalisis menggunakan uji parametrik $t$ independen, sedangkan perbedaan rerata IMT dianalisis menggunakan uji non-parametrik Mann-Whitney. Perbedaan frekuensi jenis kelamin, penyakit hipertensi, dislipidemia, diabetes melitus, obesitas sentral, dislipidemia, lingkar leher, dan tingkat risiko OSA pada kedua kelompok status fungsi kognitif global dianalisis menggunakan uji Kai-kuadrat. Perbedaan frekuensi komponen-komponen sindrom metabolik pada kedua kelompok tingkat risiko OSA dianalisis dengan menggunakan uji Kai-kuadrat. 
HASIL

Gambaran Karakteristik Demografis, Sindroma Metabolik, Tingkat Risiko OSA, dan Fungsi Kognitif Global

Penelitian ini melibatkan 89 subjek dengan rerata usia $53,7 \pm 8,2$ tahun, IMT $25,6 \pm 4,7 \mathrm{~kg} / \mathrm{m}^{2}$, dan proporsi jenis kelamin yang seimbang. Frekuensi subjek dengan penyakit hipertensi, dislipidemia, dan diabetes melitus rendah, sedangkan frekuensi subjek dengan obesitas sentral cukup tinggi. Frekuensi subjek dengan tingkat risiko tinggi OSA dan status fungsi kognitif global yang menurun relatif sebanding dengan frekuensi subjek normal (Tabel 1).

Tabel 1. Gambaran karakteristik demografis, komponen sindroma metabolik, tingkat risiko OSA, dan fungsi kognitif global

\begin{tabular}{|c|c|}
\hline Karakteristik & $\begin{array}{c}\text { Hasil } \\
(\mathrm{n}=89)\end{array}$ \\
\hline \multicolumn{2}{|l|}{ Demografis } \\
\hline - Usia dalam tahun (rerata \pm SD) & $53,7 \pm 8,2$ \\
\hline - Jenis kelamin laki-laki, n(\%) & $42(47,2)$ \\
\hline \multicolumn{2}{|l|}{ Komponen sindroma metabolik } \\
\hline - Hipertensi, $\mathrm{n}(\%)$ & $32(35,0)$ \\
\hline - $\quad$ Dislipidemia, $n(\%)$ & $12(13,6)$ \\
\hline - $\quad$ Diabetes mellitus, $(\mathrm{n} \%)$ & $11(12,4)$ \\
\hline - $\quad$ IMT dalam kg $/ \mathrm{m}^{2}$ (rerata $\left.\pm S D\right)$ & $25,6 \pm 4,7$ \\
\hline - Obesitas sentral, $\mathrm{n}(\%)$ & $59(66,3)$ \\
\hline Tingkat risiko tinggi untuk OSA, $n(\%)$ & $39(43,3)$ \\
\hline Fungsi kognitif rendah (skor CDT=0-3), n(\%) & $47(52,2)$ \\
\hline
\end{tabular}

Keterangan: IMT=Indeks Massa Tubuh, OSA=Obstructive Sleep Apnea, $\mathrm{CDT}=$ Clock Drawing Test.

Hubungan Karakteristik Demografis, Komponen Sindroma Metabolik, Tingkat Risiko OSA dengan Fungsi Kognitif Global

Pada penelitian ini, didapatkan perbedaan frekuensi penyakit diabetes melitus dan tingkat risiko OSA yang bermakna antara kelompok subjek dengan status fungsi kognitif global normal dan menurun $(p<0,05)$. Tidak terdapat perbedaan rerata usia dan IMT, frekuensi jenis kelamin, hipertensi, dislipidemia, dan obesitas sentral antara kedua kelompok status fungsi kognitif global (Tabel 2).

Tabel 2. Pengaruh karakteristik klinis dan demografis subjek terhadap fungsi kognitif global

\begin{tabular}{|c|c|c|c|}
\hline \multirow{2}{*}{ Karakteristik } & \multicolumn{2}{|c|}{ Fungsi Kognitif Global } & \multirow{2}{*}{ p-value } \\
\hline & Normal & Rendah & \\
\hline $\begin{array}{l}\text { Usia dalam tahun } \\
\text { (rerata } \pm S D \text { ) }\end{array}$ & $52,5 \pm 8,2$ & $54,7 \pm 8,2$ & $0,205^{*}$ \\
\hline \multicolumn{4}{|l|}{ Jenis kelamin, $n(\%)$} \\
\hline Laki-laki & $20(22,5)$ & $22(24,7)$ & 0,939 \\
\hline Perempuan & $22(24,7)$ & $25(28,1)$ & \\
\hline \multicolumn{4}{|l|}{ Hipertensi, n(\%) } \\
\hline Ya & $11(12,4)$ & $21(23,6)$ & 0,070 \\
\hline Tidak & $31(34,8)$ & $26(29,2)$ & \\
\hline \multicolumn{4}{|l|}{ Dislipidemia, n(\%) } \\
\hline $\begin{array}{l}\text { Ya } \\
\text { Tidak }\end{array}$ & $\begin{array}{r}5(5,6) \\
37(41,6)\end{array}$ & $\begin{array}{r}7(7,9) \\
40(44,9)\end{array}$ & 0,680 \\
\hline \multicolumn{4}{|c|}{ Diabetes melitus, n(\%) } \\
\hline $\begin{array}{l}\text { Ya } \\
\text { Tidak }\end{array}$ & $\begin{array}{r}2(2,3) \\
40(44,9)\end{array}$ & $\begin{array}{r}9(10,1) \\
38(42,7)\end{array}$ & 0,040 \\
\hline $\begin{array}{l}\text { IMT dalam kg/m² } \\
\text { (rerata } \pm S D)\end{array}$ & $25,6 \pm 5,4$ & $25,6 \pm 4,0$ & $0,551^{* *}$ \\
\hline
\end{tabular}

Tabel 2. Pengaruh karakteristik klinis dan demografis subjek terhadap fungsi kognitif global (Lanjutan)

\begin{tabular}{|c|c|c|c|}
\hline \multirow{2}{*}{ Karakteristik } & \multicolumn{2}{|c|}{ Fungsi Kognitif Global } & \multirow{2}{*}{$p$-value } \\
\hline & Normal & Rendah & \\
\hline \multicolumn{4}{|l|}{ Obesitas sentral, n(\%) } \\
\hline Normoweight & $15(16,9)$ & $15(16,9)$ & 0,705 \\
\hline Obese & $27(30,3)$ & $32(35,9)$ & \\
\hline \multicolumn{4}{|c|}{ Tingkat risiko OSA, n(\%) } \\
\hline Rendah & $29(32,6)$ & $21(23,6)$ & 0,021 \\
\hline Tinggi & $13(14,6)$ & $26(29,2)$ & \\
\hline
\end{tabular}

Keterangan: *Uji t independen, ** Uji Mann Whitney

Hubungan Komponen Sindrom Metabolik dan Tingkat Risiko OSA

Hasil penelitian menunjukkan terdapat perbedaan frekuensi hipertensi yang bermakna antara kelompok risiko tinggi dan rendah untuk terjadinya OSA $(p<0,001)$. Tidak terdapat perbedaan bermakna dalam hal frekuensi dislipidemia, obesitas sentral, dan diabetes melitus diantara kedua kelompok tingkat risiko OSA (Tabel 2).

Tabel 2. Hubungan komponen sindrom metabolik dan tingkat risiko OSA

\begin{tabular}{|c|c|c|c|}
\hline \multirow{2}{*}{ Karakteristik } & \multicolumn{2}{|c|}{ Tingkat Risko OSA } & \multirow{2}{*}{ p-value } \\
\hline & Rendah & Tinggi & \\
\hline \multicolumn{4}{|l|}{ Hipertensi, n(\%) } \\
\hline Yaff & $9(10,1)$ & $23(25,8)$ & 0,000 \\
\hline Tidak & $41(46,1)$ & $16(18,0)$ & \\
\hline \multicolumn{4}{|l|}{ Dislipidemia, n(\%) } \\
\hline Ya & $7(7,9)$ & $5(5,6)$ & 0,872 \\
\hline Tidak & $43(48,3)$ & $34(38,2)$ & \\
\hline \multicolumn{4}{|c|}{ Obesitas sentral, $\mathrm{n}(\%)$} \\
\hline Normal & $17(13,5)$ & $13(18,0)$ & 0,947 \\
\hline Obese & $33(42,7)$ & $26(25,8)$ & \\
\hline \multicolumn{4}{|c|}{ Diabetes melitus, n (\%) } \\
\hline $\mathrm{Ya}$ & $4(4,5)$ & $7(7,9)$ & 0,138 \\
\hline Tidak & $46(51,7)$ & $32(35,9)$ & \\
\hline
\end{tabular}

Keterangan: Uji Kai-kuadrat

\section{DISKUSI}

Penelitian ini ditujukan untuk menginvestigasi hubungan faktor dan tingkat risiko OSA terhadap fungsi kognitif global. Hasil penelitian menunjukkan bahwa pada kelompok subjek dengan tingkat risiko tinggi untuk terjadinya OSA, frekuensi subjek dengan fungsi kognitif global menurun secara bermakna lebih tinggi dibandingkan dengan frekuensi subjek dengan fungsi kognitif global normal. Obstructive Sleep Apnea (OSA) memiliki keterkaitan dengan terjadinya penurunan fungsi kognitif $(3,20,21)$. Patofisiologi terjadinya penurunan fungsi kognitif pada pasien OSA diawali dengan terjadinya hipoksia intermiten yang menginduksi terjadinya peningkatan aktivitas sistem saraf simpatis (24). Peningkatan aktivitas sistem saraf simpatis tersebut akan menginduksi serangkaian proses, secara berturut-turut meliputi vasokonstriksi pembuluh darah otak, disfungsi endotel pembuluh darah tersebut, respon inflamasi berlebihan, dan kerusakan sawar darah-otak (3). Kerusakan pada sawar darah-otak menyebabkan terjadinya perubahan struktural dan fungsional jaringan otak, termasuk jaringan otak yang mengemban fungsi 
kognitif, yang mengarah pada proses neurodegenerasi (25). Bagian otak yang penting untuk terbentuknya fungsi kognitif yang rentan mengalami penurunan volume dan fungsinya akibat proses tersebut adalah hipokampus, lobus frontal, parietal, dan temporal (24). Populasi neuron pada ketiga bagian otak tersebut sensitif terhadap kondisi hipoksia, sehingga kondisi hipoksia intermiten yang berlangsung lama akan menyebabkan kerusakan pada populasi neuron tersebut.

Hasil penelitian ini menunjukkan bahwa pada subjek dengan diabetes melitus sebagai faktor risiko OSA, frekuensi subjek dengan penurunan fungsi kognitif global secara bermakna lebih tinggi dibandingkan dengan subjek dengan fungsi kognitif normal. Proporsi komponen sindrom metabolik lainnya, yaitu hipertensi, dislipidemia, dan obesitas sentral tidak berbeda bermakna menurut fungsi kognitif global. Obstructive Sleep Apnea memiliki hubungan dua arah dengan sindrom metabolik, yaitu komponen sindrom metabolik meningkatkan risiko terjadinya OSA, begitu juga sebaliknya (1). Peningkatan aktivitas sistem saraf simpatis yang ditemukan pada OSA, juga bisa ditemukan pada sindrom metabolik yang dapat terjadi secara independen maupun ditingkatkan oleh OSA $(26,27)$. Berdasarkan beberapa penelitian sebelumnya, sindrom metabolik juga memiliki keterkaitan dengan kejadian penurunan fungsi kognitif (28-30). Oleh karena itu peningkatan risiko terjadinya OSA akibat adanya komponen-komponen sindrom metabolik juga bisa menyebabkan terjadinya penurunan fungsi kognitif.

Peran diabetes melitus terhadap penurunan fungsi kognitif dapat merupakan pengaruh dari diabetes melitus secara independen atau melalui pengaruhnya terhadap peningkatan risiko OSA (31-34). Untuk mengetahui peran

\section{DAFTAR PUSTAKA}

1. Xu S, Wan Y, Xu M, Ming J, Xing Y, An F, and Ji Q. The Association between Obstructive Sleep Apnea and Metabolic Syndrome: A Systematic Review and Meta-analysis. BMC Pulmonary Medicine. 2015; 15: 105-117.

2. Kasai T, Floras JS, and Bradley TD. Sleep Apnea and Cardiovascular Disease: A Bidirectional Relationship. Circulation. 2012; 126(12): 1495-1510.

3. Lim DC and Pack Al. Obstructive Sleep Apnea and Cognitive Impairment: Addressing the Blood-Brain Barrier. Sleep Medicine Reviews. 2014; 18(1): 35-48.

4. Senaratna CV, Perret JL, Lodge CJ, et al. Prevalence of Obstructive Sleep Apnea in the General Population: A Systematic Review. Sleep Medicine Reviews. 2017; 34: 70-81.

5. Gunawan P, Harris S, and Octaviana F. Prevalence of Obstructive Sleep Apnea Using the STOP-Bang Questionairre and Its Correlation to Other Stroke Risk Factors in the Normal Population. Sleep Medicine. 2016;16(1):S81-S85.

6. Aurora RN, Zak RS, Karippot A, et al. Practice Parameters for the Respiratory Indications for Polysomnography in Children. Sleep. 2011; 34(3): 379-388.

7. Chung F, Abdullah HR, and Liao P. STOP-Bang Questionnaire: A Practical Approach to Screen for diabetes melitus terhadap tingkat risiko OSA, dalam penelitian ini juga dilakukan analisis terhadap hubungan diabetes melitus dan keempat komponen sindrom metabolik lainnya dengan peningkatan risiko OSA. Hasil penelitian ini menunjukkan bahwa proporsi diabetes melitus, dislipidemia, dan obesitas sentral tidak berbeda secara bermakna menurut tingkat risiko OSA. Hasil tersebut mengkonfirmasi bahwa diabetes melitus secara independen berperan dalam penurunan fungsi kognitif global. Sebaliknya hasil penelitian mengindikasikan bahwa hipertensi berhubungan dengan fungsi kognitif tidak secara independen, melainkan melalui perannya dalam meningkatkan risiko terjadinya OSA.

Tatalaksana lebih dini terhadap penurunan fungsi kognitif yang terkait dengan OSA akan memberikan hasil yang memuaskan dibandingkan dengan penatalaksanaan pada tahap lanjut (22). Mengingat penegakan diagnosis OSA memiliki keterbatasan, sedangkan prevalensi OSA di populasi umum cukup tinggi namun jarang terdiagnosis (23), maka penapisan tingkat risiko OSA dan penurunan fungsi kognitif terkait dengan tingkat risiko OSA tersebut menjadi penting. Studi lanjut perlu dilakukan menggunakan pemeriksaan polisomnografi pada subjek dengan risiko tinggi OSA untuk penegakan diagnosis OSA, sebagai dasar untuk mengkaji hubungan antara tingkat risiko OSA, diagnosis OSA, dan status fungsi kognitif global.

Dapat disimpulkan bahwa tingkat risiko OSA berhubungan dengan penurunan fungsi kognitif global pada subjek subpopulasi Kota Mataram. Komponen sindrom metabolik yang merupakan komorbid pada subjek dengan risiko tinggi untuk OSA dalam menimbulkan efek penurunan fungsi kognitif adalah diabetes melitus dan hipertensi.

Obstructive Sleep Apnea. Chest. 2016; 149(3): 631638.

8. Nagappa M, Liao P, Wong J, et al. Validation of the STOP-Bang Questionnaire as a Screening Tool for Obstructive Sleep Apnea among Different Populations: A Systematic Review and MetaAnalysis. Plos One. 2015; 10(12): e0143697 (1-21).

9. Doshi V, Walia R, Jones $\mathrm{K}$, Aston $\mathrm{CE}$, and Awab A. STOP-BANG Questionnaire as a Screening Tool for Diagnosis of Obstructive Sleep Apnea by Unattended Portable Monitoring Sleep Study. SpringerPlus. 2015; 4: 795-799.

10. Pavarangkul $\mathrm{T}$, Jungtrakul $\mathrm{T}$, Chaobangprom $\mathrm{P}$, et al. The STOP-BANG Questionnaire as a Screening Tool for Obstructive Sleep Apnea Induced Hypertension in Asian Population. Neurology International. 2016; 8(1): 6104-6107.

11. Daulatzai MA. Pathogenesis of Cognitive Dysfunction in Patients with Obstructive Sleep Apnea: A Hypothesis with Emphasis on the Nucleus Tractus Solitarius. Sleep Disorders. 2012; 251096: 1-18.

12. Canessa N, Castronovo V, Cappa SF, et al. Obstructive Sleep Apnea: Brain Structural Changes and Neurocognitive Function Before and After Treatment. American Journal of Respiratory and Critical Care Medicine. 2011; 183(10): 1419-1426.

13. Drager LF, Genta PR, Pedrosa RP, et al. Characteristics 
and Predictors of Obstructive Sleep Apnea in Patients with Systemic Hypertension. The American Journal of Cardiology. 2010; 105(8): 1135-1139.

14. Hein $\mathrm{M}$, Lanquart JP, Loas $\mathrm{G}$, Hubain $\mathrm{P}$, and Linkowski P. Prevalence and Risk Factors of Moderate to Severe Obstructive Sleep Apnea Syndrome in Insomnia Sufferers: A Study on 1311 Subjects. Respiratory Research. 2017; 18: 135-144.

15. Harahap HS, Padauleng N, Rizki M, Pintaningrum $Y$, and Indrayana Y. Gambaran Skor Risiko Stroke Framingham, Obesitas, Dislipidemia, dan Hiperurisemia pada Penduduk Kecamatan Sekarbela Mataram. Jurnal Kedokteran Brawijaya. 2017; 29(3): 244-248.

16. Alberti KG, Eckel RH, Grundy SM, et al. Harmonizing the Metabolic Syndrome: A Joint Interim Statement of the International Diabetes Federation Task Force on Epidemiology and Prevention; National Heart, Lung, and Blood Institute; American Heart Association; World Heart Federation; International Atherosclerosis Society; and International Association for the Study of Obesity. Circulation. 2009; 120(16): 1640-1645.

17. Paula JJ, Miranda DM, Moraes EN, and Malloy-Diniz LF. Mapping the Clock Works: What Does the Clock Drawing Test Assess in Normal and Pathological Aging? Arquivos de Neuropsiquiatria. 2013; 71(10): 763-768.

18. Hartati S and Widayanti CG. Clock Drawing: Asesmen untuk Demensia (Studi Deskriptif pada Orang Lanjut Usia di Kota Semarang). Jurnal Psikologi Undip. 2010; 7(1): 1-9.

19. Kelompok Studi Fungsi Luhur. Panduan Pemeriksaan Neurologi dan Neurobehavior. Jakarta: PERDOSSI; 2010; hal. 1-12.

20. Bawden FC, Oliveira CA, and Caramelli P. Impact of Obstructive Sleep Apnea on Cognitive Performance. Arquivos de Neuro-psiquiatria. 2011; 69(4): 585-589.

21. Vitale GJ, Capp K, Ethridge K, et al. Sleep Apnea and the Brain: Neurocognitive and Emotional Considerations. Journal of Sleep Disorders and Management. 2016; 2(1): 8-12.

22. Langa KM and Levine DA. The Diagnosis and Management of Mild Cognitive Impairment: A Clinical Review. The Journal of the American Medical Association. 2014; 312(23): 2551-2561.
23. Correa CC, Blasca WQ, and Berretin-Felix G. Health Promotion in Obstructive Sleep Apnea Syndrome. International Archives of Otorhinolaryngology. 2015; 19(2): 166-170.

24. Lal C, Strange C, and Bachman D. Neurocognitive Impairment in Obstructive Sleep Apnea. Chest. 2012; 141(6): 1601-1610.

25. Dewan NA, Nieto FJ, and Somers VK. Intermittent Hypoxemia and OSA: Implications for Comorbidities. Chest. 2015; 147(1): 266-274.

26. Moreira MCS, Pinto ISJ, Mourāo AA, et al. Does the Sympathetic Nervous System Contribute to the Pathophysiology of Metabolic Syndrome? Frontiers in Physiology. 2015; 6: 234-244.

27. Grassi G, Seravalle G, Quarti-Trevano F, et al. Reinforcement of the Adrenergic Overdrive in the Metabolic Syndrome Complicated by Obstructive Sleep Apnea. Journal of Hypertension. 2010; 28(6): 1313-1320.

28. Cavalieri M, Ropele S, Petrovic K, et al. Metabolic Syndrome, Brain Magnetic Resonance Imaging, and Cognition. Diabetes Care. 2010; 33(12): 2489-2495.

29. Oh H, Kim SH, Kang SG, Park SJ, and Song SW. The Relationship between Metabolic Syndrome and Cognitive Function. Korean Journal of Family Medicine. 2011; 32(6): 358-366.

30. Tsai CK, Kao TW, Lee JT, et al. Increased Risk of Cognitive Impairment in Patients with Components of Metabolic Syndrome. Medicine. 2016; 95(36): 1-5.

31. Saedi E, Gheini MR, Faiz F, and Arami MA. Diabetes Mellitus and Cognitive Impairments. World Journal of Diabetes. 2016; 7(17): 412-422.

32. Munshi MN. Cognitive Dysfunction in Older Adults with Diabetes: What a Clinician Needs to Know. Diabetes Care 2017; 40(4): 461-467.

33. Li $\mathrm{H}$, Gong $\mathrm{Q}$, Shao J, Liu $\mathrm{X}$, and Zhao Y. Cognitive Dysfunction in Type 2 Diabetes Patients Accompanied with Obstructive Sleep Apnea Syndrome. Pakistan Journal of Medical Sciences 2014; 30(6): 1388-1392.

34. Lailiyya N and Putra BA. Risk of Cognitive Impairment in Type 2 Diabetes Patients with Obstructive Sleep Apnea Risk in Hasan Sadikin Hospital Bandung. Sleep Medicine. 2017; 40: 176-180. 